\author{
Marzanna Bogumila Kielar \\ Akademia Pedagogiki Specjalnej \\ w Warszawie
}

\title{
Integralny Pluralizm Metodologiczny - nowe podejście w badaniach edukacyjnych
}

\section{Teoria integralna}

Integralny Pluralizm Metodologiczny wyrasta z teorii integralnej, której twórcą jest współczesny amerykański psycholog i filozof, Ken Wilber. Prace nad nią rozpoczął on na początku lat 70. ubiegłego wieku, co po latach zaowocowało wszechstronnym podejściem integralnym, obejmującym całość ludzkiego doświadczenia. Budując teorię integralną, amerykański badacz uznał podstawowe (choć niepełne) rozstrzygnięcia węższych podejść i - odrzucając ich ekstremistyczne wypaczenia włączył je w swój ogląd rzeczy, tworząc syntezę wyższego rzędu. Wilber wiąże imponującą liczbę znaczących rozstrzygnięć ze wszystkich głównych dziedzin wiedzy - na poziomie orientujących uogólnień (tj. ogólnych prawd, co do których panuje niemal powszechna zgoda) - w pełną, logiczną i wiarygodną wizję.

Jeśli ta wszechstronna synteza jest słuszna, wskazuje Jack Crittenden z Arizona State University, to uznaje ona i zawiera więcej prawdy niż jakikolwiek system w historii. Podkreśla on zarazem, że Wilber nie oferuje nam konceptualnego kaftana bezpieczeństwa, a orientującą integralną mapę, która pokazuje, że w Kosmosie jest więcej miejsca niż się spodziewaliśmy ${ }^{1}$. Jest to mapa nieustannie poddawana rewizji i wciąż uaktualniana dzięki wykorzystaniu krytyki i nowych dowodów dostarczanych przez naukę.

Prace na rzecz osadzenia teorii integralnej w dyskursie akademickim i uczynienia z niej uznanej dziedziny naukowej rozpoczęły się zaledwie kilka lat temu i znalazły wyraz w takich przedsięwzięciach, jak 2 : 1 . Recenzowany kwartalnik akademicki - „Journal of Integral Theory and Practice” (ukazuje się od 2005 r.), specjalizujący

\footnotetext{
${ }^{1}$ Por. J. Crittenden, What Is the meaning of „Integral”?, [w:] K. Wilber, The eye of spirit, Boston-London 2001, s. XIII.

${ }^{2}$ Por. S. Esbjörn-Hargens, Introduction, [w:] Integral theory in action. Applied, theoretical, and constructive perspectives on the AQAL Model, red. S. Esbjörn-Hargens, New York 2010, s. 1-12; tenże, Editorial introduction, „Journal of Integral Theory and Practice” 2008, t. 3, No 1, s. V-IX.
} 
się w zastosowaniach teorii integralnej; 2. Program uniwersytecki (studia stacjonarne i on-line, od 2006 r.) - oparty na teorii integralnej (John F. Kennedy University oraz Fielding Graduate University); 3. Uniwersyteckie centrum badawcze (Integral Research Center, otwarte w roku 2008); 4. Międzynarodowa konferencja naukowa (od 2008 r.); 5. Akademicka seria wydawnicza - SUNY Press, wydawnictwo State University of New York, rozpoczęło w 2009 r. publikację serii książkowej poświęconej teorii integralnej i jej zastosowaniom.

Teoria integralna Wilbera znalazła dotychczas zastosowanie w ponad 35, często odległych od siebie, dziedzinach: od medycyny przez psychologię, psychofarmakologię, zarządzanie, politykę, ekonomię, prawo, teorię sztuki do futurologii, ekologii i edukacji, by wymienić tylko niektóre $\mathrm{z}$ tych dyscyplin ${ }^{3}$. Te zastosowania świadczą o jej wszechstronności. Teoria integralna jest użyteczna zarówno w skali małej (np. w indywidualnej psychoterapii), średniej (np. w przeprowadzaniu zmian organizacyjnych i rozwijaniu kultur organizacyjnych), jak i w projektach o zasięgu globalnym (np. program ONZ „Leadership for Results”, zastosowany w ponad 30 krajach w ramach walki z HIV/AIDS).

Będąca syntezą dostępnej wiedzy teoria integralna Wilbera opiera się na modelu AQAL ${ }^{4}$ i jego pięciu elementach składowych oraz na Integralnym Pluralizmie Metodologicznym (Integral Methodological Pluralism - IMP) ${ }^{5}$. Strukturę przedstawionego przez Wilbera w 1995 r. meta-modelu AQAL tworzy co najmniej pięć elementów: 1) ćwiartki (four quadrants), czyli podstawowe wymiary doświadczenia; 2) poziomy (levels) egzystencji: ciało, umysł, duch; 3) linie (lines) rozwoju (poznawcza, moralna, interpersonalna i in.); 4) stany (states) świadomości, np. jawa, sen, marzenie; 5) typy (types), np. charakteryzujące płeć, osobowość.

Wymienione składowe modelu AQAL przedstawiają podstawowe, powtarzające się wzory rzeczywistości, które powracają w różnorodnych i złożonych kontekstach. Model ten obejmuje fizyczne, mentalne i duchowe poziomy rzeczywistości z perspektywy czterech wymiarów doświadczania - subiektywnego, intersubiektywnego, obiektywnego i interobiektywnego.

\section{Cztery ćwiartki - cztery wymiary istnienia}

Model czterech ćwiartek - kluczowy w kontekście Integralnego Pluralizmu Metodologicznego - można przedstawić na dwa sposoby. Możemy potraktować ćwiartki jako wymiary oraz jako perspektywy. Cztery ćwiartki reprezentują

\footnotetext{
${ }^{3}$ Por. S. Esbjörn-Hargens, An overview of integral theory: An all-inclusive framework for the twenty-first century, [w:] Integral theory in action..., s. 34.

${ }^{4}$ Nazwa AQAL jest akronimem i oznacza: all quadrants, all levels, tj. wszystkie ćwiartki, wszystkie poziomy rzeczywistości.

${ }^{5} \mathrm{~K}$. Wilber, Integral spirituality. A startling new role for religion in the modern and postmodern word, Boston-London 2007, s. 1-102, 142-178, 207-301.
} 
cztery podstawowe wymiary istnienia w rzeczywistości: wewnętrzny (intencjonalny) i zewnętrzny (behawioralny) świat jednostki oraz wewnętrzny (kulturowy) i zewnętrzny (społeczny) świat zbiorowości.

Górna Lewa ćwiartka (GL) ukazuje subiektywny, wewnętrzny świat jednostki, jej umysł, indywidualną świadomość i stany psychiki. Metodologicznie ujmując, wymiar ten jest dostępny $\mathrm{m}$. in. poprzez dialog $\mathrm{z}$ osobą, analizę jej prywatnych dokumentów (np. dzienniki, pamiętniki), introspekcję, psychoanalizę, wywiady $\mathrm{i}$ in. Wymiar ten można opisać w języku pierwszej osoby - „Ja”.

Górna Prawa ćwiartka (GP) reprezentuje obiektywne, to jest zewnętrzne odpowiedniki wewnętrznych stanów świadomości. To materialny mózg i jego obiektywne komponenty. Językiem tej behawioralnej ćwiartki jest język trzeciej osoby: „To”. Wymiar ten jest dostępny m. in. poprzez obserwację empiryczną, rygorystyczne pomiary i analizy.

Dolna Lewa ćwiartka (DL) określa wymiar kulturowy lub, innymi słowy, wewnętrzną świadomość grupy/zbiorowości. Są to powszechnie obowiązujące światopoglądy, konteksty i znaczenia tworzone przez wspólny sposób postrzegania świata, wspólne wartości i wspólnie przeżywaną historię. Ten wewnętrzny obszar zbiorowości daje się opisać w języku „Ty/My”. Wymiar kulturowy staje się dostępny dzięki antropologii kulturowej, etnometodologii, hermeneutyce.

Dolna Prawa ćwiartka (DP) to zewnętrzne - materialne i instytucjonalne - formy życia zbiorowości. To także środowisko i świat fizyczny stworzone zarówno przez naturę, jak i człowieka. Język tej ćwiartki to występujące w trzeciej osobie „Te”. Wymiar ten odsłaniają $\mathrm{m}$. in. badania empiryczne i analizy statystyczne (por. ryc. 1).

Wymienione wymiary to zarazem cztery główne perspektywy: Ja, My, To, Te. Wilber przybliża je na przykładzie obserwacji świadomości. I tak, na świadomość osoby możemy patrzeć od środka bądź z zewnątrz:

- spojrzenie subiektywne (perspektywa Ja): obserwuję moją świadomość w tym momencie, patrzę na nią od środka, widząc moje uczucia, nadzieje, radości, obawy etc.,

- spojrzenie obiektywne (perspektywa To): moja świadomość może być widziana z zewnątrz, w obiektywny, naukowy sposób, np. mogę wnioskować, że jest ona wytworem procesów mózgowych i sieci neurofizjologicznych.

Możemy również patrzeć, w jaki sposób świadomość istnieje jako część grupy lub zbiorowości. I tak jak patrzymy od środka lub z zewnątrz na świadomość indywidualną, tak samo możemy ujrzeć - od środka bądź z zewnątrz - świadomość zbiorowości (rodziny, korporacji, klanu, narodu, uczniów w klasie etc.).

- spojrzenie intersubiektywne (perspektywa My): dostrzegamy m. in. światopoglądy dzielone przez grupy ludzi (np. magiczny, mityczny, racjonalny), wspólne wartości, etykę, zwyczaje etc.,

- spojrzenie interobiektywne (perspektywa Te): widzimy obiektywne struktury i instytucje społeczne zbiorowości (budynki, infrastruktura, baza 
techniczno-ekonomiczna), ilościowe aspekty społeczności (obiektywne dane, wskaźniki narodzin i zgonów itp.), sposoby komunikacji (np. słowo pisane, telefon, Internet) etc.

Górna Lewa

Górna Prawa

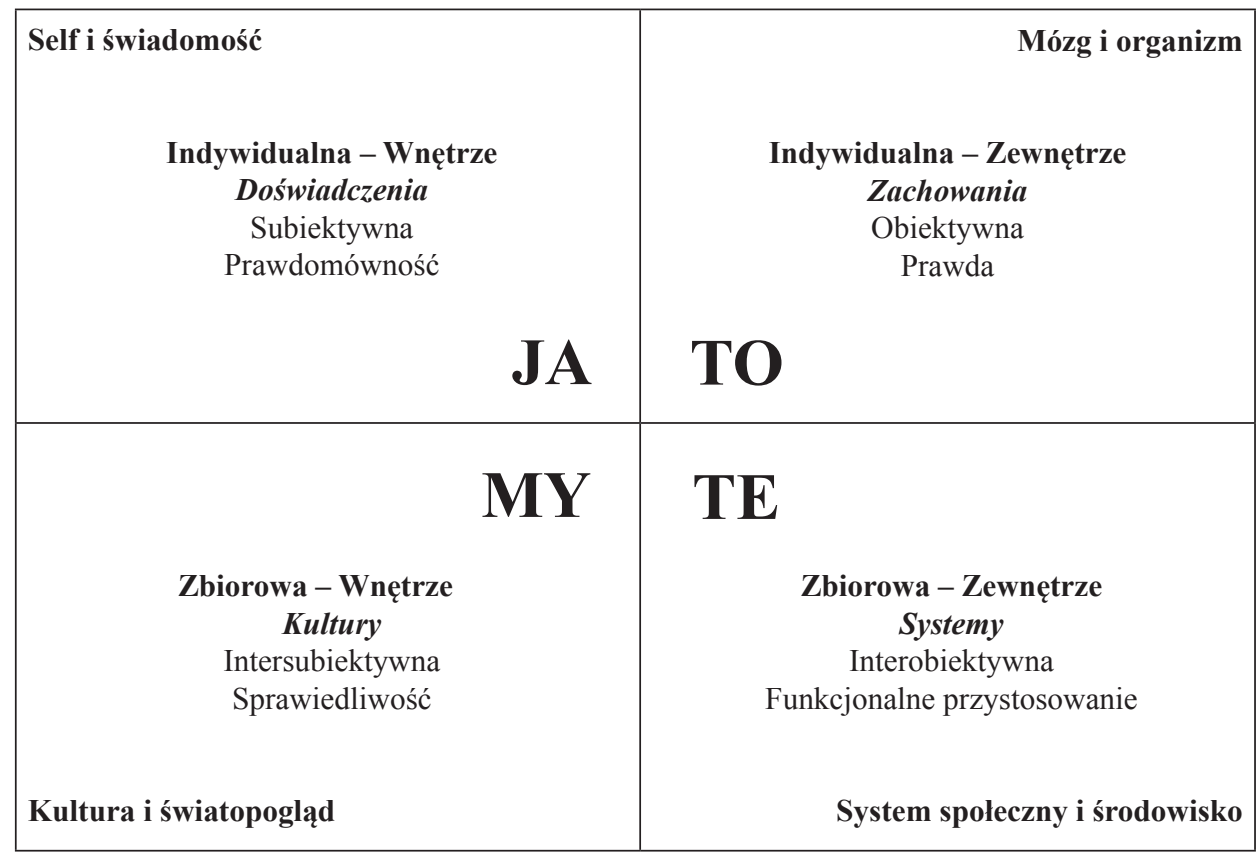

Dolna Lewa

Dolna Prawa

Ryc. 1. Niektóre aspekty czterech ćwiartek

Źródło: S. Esbjörn-Hargens, K. Wilber, Toward a comprehensive integration of science and religion: A post-metaphysical approach, [w:] The Oxford handbook of religion and science, eds P. Clayton, Z. Simpson, Oxford 2006, s. 526

Ćwiartki to cztery wymiary - perspektywy istnienia podmiotu w rzeczywistości, cztery drogi dotykania i doświadczania przez podmiot rzeczywistości w danym momencie. Te cztery wymiary istnienia są tak samo istotne, żaden z nich nie jest bardziej rzeczywisty czy ważniejszy od pozostałych, i żadnego nie wolno sprowadzać do pozostałych, podkreśla Wilber. Każdy z tych czterech wymiarów istnienia charakteryzuje się wzrostem, rozwojem i ewoluuje, a także współewoluuje z pozostałymi. Wzory rozwoju, który postępuje poprzez poziomy o coraz większym stopniu złożoności, widoczne są zarówno w jednostkach, jak 
i w ewolucji ludzkich społeczności czy świata natury (np. w ćwiartce GL można obserwować ewolucję świadomości indywidualnej; w DL - ewolucję kulturową; w GP - ewolucję fizyczną; w DP - ewolucję społeczeństw). Każdy z tych wymiarów ma odmienne kontury i rodzaje danych, a także własny rodzaj prawdy oraz kryteria potwierdzania słuszności (por. ryc. 2). Każdy z wymiarów ma dostosowane do siebie różnorodne formy badań.

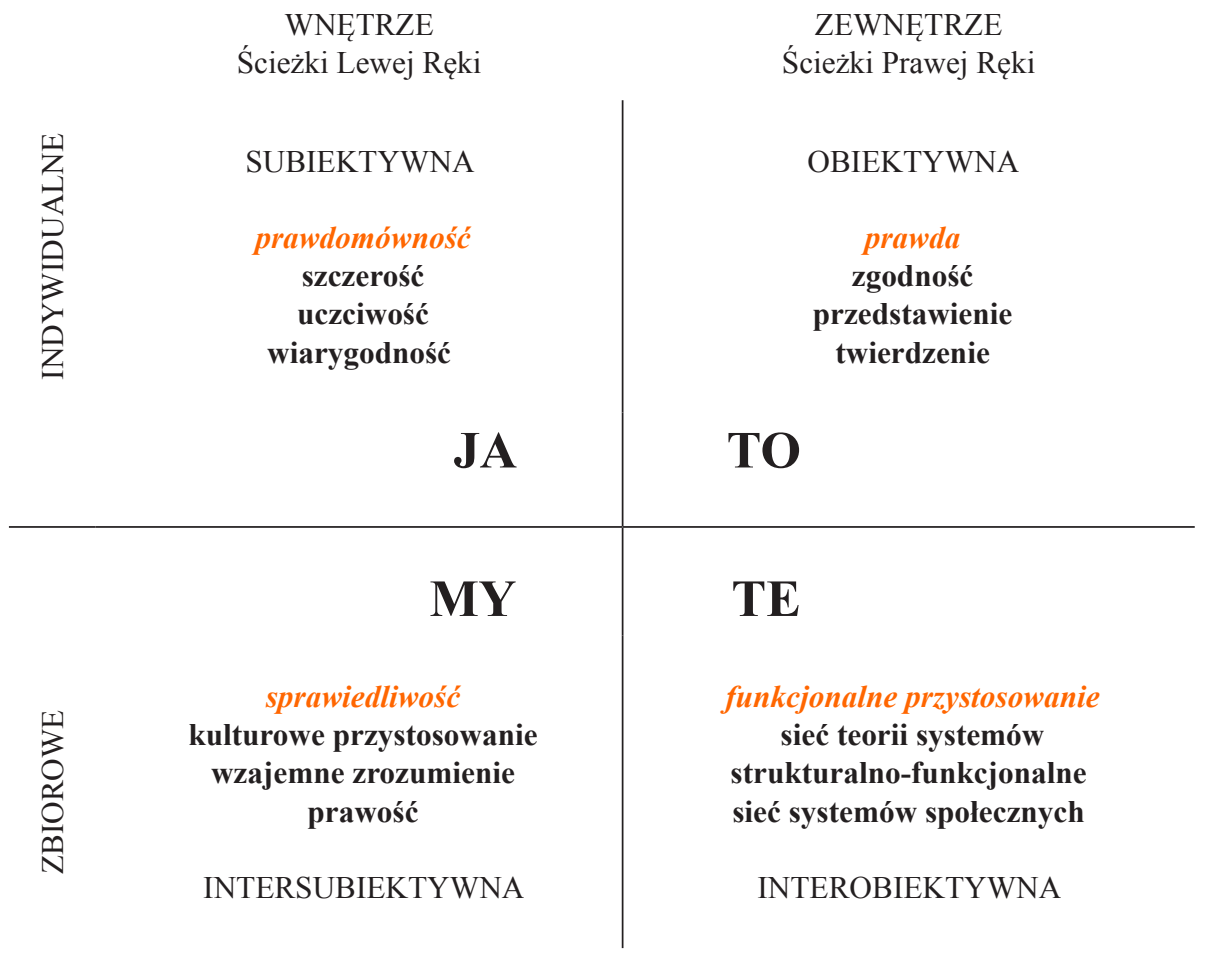

Ryc. 2. Niektóre rodzaje prawdy charakterystyczne dla czterech ćwiartek oraz potwierdzenia słuszności

Źródło: K. Wilber, The eye of spirit, Boston-London 2001, s. 12

\section{Trzy sekwencje uprawnionego poznania naukowego}

Wilber przyjmuje, że badaniem w każdej ćwiartce kierują trzy sekwencje wszelkiego uprawnionego poznania naukowego, będące jądrem każdej metodologii przynoszącej ważne dane ${ }^{6}$ :

${ }^{6}$ Por. K. Wilber, Małżeństwo rozumu z dusza. Integracja nauki i religii, przekł. H. Smagacz, Warszawa 2008, s. 161-166. 
1. Instrumentalne zalecenie - paradygmat ${ }^{7}$, eksperyment, nakaz. Praktyka ta zawsze przyjmuje formę wskazania: „Jeśli chcesz poznać to zjawisko, wykonaj to działanie". Na przykład przedstaw założenia, podejmij i przeprowadź czynności praktyczne w określonych warunkach, tak, aby inni badacze mogli powtórzyć badanie i otrzymać takie same wyniki.

2. Bezpośrednie zrozumienie - doświadczenie, zrozumienie bądź iluminacja uzyskanych danych (Wilber używa terminu ,dane" w znaczeniu zaproponowanym przez Williama Jamesa: natychmiastowe doświadczenie, doznanie czegoś).

3. Wspólne potwierdzenie (lub odrzucenie) - falsyfikowalność ${ }^{8}$, tj. sprawdzenie wyników badania (danych, dowodów) i porównanie ich z wynikami otrzymanymi przez inne osoby, które kierowały się instrumentalnym zaleceniem, a następnie zgromadziły empiryczne dowody.

Powyższe trzy sekwencje poznania naukowego stosują się do każdej wartościowej wiedzy - na każdym poziomie egzystencji (sensorycznym, mentalnym i duchowym), a także w każdym wymiarze doświadczenia (tj. w każdej z czterech ćwiartek) - twierdzi Wilber, znajdując oparcie w szeroko pojętym empiryzmie. Empiryzm w najszerszym rozumieniu oznacza bezpośrednie doświadczenie w ogólności i jest przeciwieństwem wąskiego empiryzmu, który ogranicza się wyłącznie do doświadczenia sensorycznego ${ }^{9}$. Szeroko ujęty empiryzm stanowi,

${ }^{7}$ Wilber przywraca pierwotne znaczenie pojęcia paradygmat, tj. to, które Thomas Khun wprowadził do nauki w 1962 r., publikując Strukturę rewolucji naukowych. Wilber przypomina, że Kuhn najczęściej używał słowa paradygmat w znaczeniu instrukcji, tj. „operacji zmiany narzędzi z ważnymi konsekwencjami dla praktyki badawczej”. Ta instrukcja, wzór czy praktyka społeczna, czyli paradygmat jest gwarantem postępu naukowego - odkrywa bowiem dowody, a nie fabrykuje ich na podstawie zwykłych konwencji. Tymczasem - opacznie odczytując Kuhna - przyjęto, że paradygmat nie jest zakotwiczony w faktach i dowodach, a zamiast tego je tworzy. Konsekwencją tego był pogląd, że nauka jest tylko jedną z wielu interpretacji tekstu świata i nie posiada większego autorytetu niż poezja czy chiromancja. Wilber (za Crewsem) nazywa tę błędną interpretację Kuhna teoretycyzmem, co oznacza przekonanie pogrążone w abstrakcyjnej teorii oderwanej od rzeczywistych dowodów. Teoretycyzm zakładał, że można odrzucić gorset nauki i dowodów poprzez wymyślenie nowego paradygmatu. Wilber pisze: „Żądanie dowodów - lub potwierdzenia słuszności - które zawsze zakotwiczało autentyczną i postępową naukę, oznacza po prostu, że czyjeś ego nie może narzucać wszechświatowi wizji rzeczywistości, która nie znajduje poparcia w samym wszechświecie. Potwierdzenia słuszności i dowody pozwalają nam zestroić się z kosmosem. Potwierdzenia słuszności zmuszają nas do skonfrontowania się z rzeczywistością; powściągają nasze egoistyczne fantazje i nasz egocentryzm; żądają dowodów z pozostałej części kosmosu; zmuszają nas do przekroczenia siebie!” - tamże, s. 43. Więcej na ten temat - tamże, s. 37-50.

${ }^{8}$ Wilber wskazuje, że zasada falsyfikowalności Karla Poppera ma obecnie tylko jedno ogólne zastosowanie, w dodatku opaczne, ograniczające ją ,wyłącznie do danych sensorycznych”. To sprawia, że automatycznie odmawia się statusu autentycznej wiedzy doświadczeniu mentalnemu i duchowemu. U źródeł tego nieuzasadnionego ograniczenia zasady falsyfikowalności leży chęć oddzielenia wiedzy autentycznej od dogmatycznej. Jednakże, dowodzi Wilber, w istocie prowadzi to jedynie do redukcjonizmu - tamże, s. 165-166.

${ }^{9}$ Wilber wytyka zwolennikom wąskiego empiryzmu błąd, który polega na niedostrzeganiu przez nich, że oprócz doświadczenia sensorycznego istnieją doświadczenie mentalne i duchowe. 
zdaniem Wilbera, podstawowy czynnik procedur potwierdzania słuszności w każdym obszarze. Filozof pisze:

W istocie, używając pojęcia „empiryczny” w ogólnym sensie „żądania opartych na doświadczeniu dowodów", uważam siebie za zagorzałego empirystę. Bowiem faktem jest, że istnieje doświadczenie sensoryczne, doświadczenie mentalne i doświadczenie duchowe - a empiryzm w najszerszym sensie oznacza, że zawsze uciekamy się do doświadczenia, żeby oprzeć na nim swoje twierdzenia dotyczące któregoś z tych obszarów (sensorycznego, mentalnego, duchowego).

A zatem jest empiryzm sensoryczny (świata sensoryczno-motorycznego), empiryzm mentalny (obejmujący logikę, matematykę, semiotykę, fenomenologię i hermeneutykę) oraz empiryzm duchowy (mistycyzm oparty na doświadczeniu, doświadczenia duchowe) ${ }^{10}$.

Fundament powyższego Wilber nakreślił w swojej wczesnej książce pt. Eye to eye: The quest for the new paradigm (1983), gdzie bada trzy dziedziny wiedzy: empiryczną dziedzinę zmysłów, racjonalną dziedzinę umysłu i kontemplacyjną dziedzinę ducha ${ }^{11}$. Filozof odwołuje się do chrześcijańskich mistyków, św. Bonawentury i Hugona od św. Wiktora, którzy utrzymywali, że każdy człowiek posiada „troje oczu poznania”: monologiczne „oko cielesne” (empiryzm), dialogiczne „oko umysłu” (racjonalizm) i translogiczne „oko kontemplacji” (mistycyzm). Każde z tych trojga oczu poznania, w odpowiadającej mu dziedzinie, przynosi inne dane - „sensibilia, intelligibilia i transcendelia” - odkrywając inny świat, z innym światopoglądem, odmiennym sposobem odczuwania czasu i postrzegania przestrzeni etc. Tym trzem sposobom poznania i odkrywanym przez nie rodzajom danych, Wilber przyznaje na równi status wartościowej wiedzy. Przestrzega on zarazem przed popełnieniem ,błędu kategorii”, który polega na pomyleniu poziomów, tj. na próbie uchwycenia okiem cielesnym i okiem umysłu rzeczywistości, która otwiera się jedynie przed okiem ducha ${ }^{12}$.

Uznanie powyższych sposobów badania jest pochodną rozpoznania wszystkich poziomów oraz wymiarów rzeczywistości ${ }^{13}$. Ograniczając się wyłącznie

Zwolennicy Kuhna są w błędzie, nie przyjmując do wiadomości, że „instrumentalne zalecenia” stosują się nie tylko do nauki sensoryczno-motorycznej, ale do wszystkich form uprawnionego poznania, utrzymuje. Por. tamże, s. 165.

${ }^{10}$ Tamże, s. $158-159$.

${ }^{11}$ Por. K. Wilber, Eye to eye: The quest for the new paradigm, [w:] The collected works of Ken Wilber, t. 3, Boston-London 1999, s. 139-149, 153-226.

12 Jak pisze Wilber, błąd kategorii polega na ,głębokim niezrozumieniu natury i roli monologicznej nauki, dialogicznej filozofii i translogicznej duchowości. Powinniśmy integrować je takimi, jakie są, a nie zniekształcać w monologicznym zrównywaniu niwelującym różnice, które powinny być zintegrowane przede wszystkim" - K. Wilber, Matżeństwo rozumu z du$s z q \ldots$, s. 147.

${ }^{13}$ Por. K. Wilber, The great chain of being, „Journal of Humanistic Psychology” 1993, t. 33, No 3, s. 64. 
do „oka cielesnego”, otrzymamy np. behawioryzm w psychologii i pozytywizm w filozofii. Wprowadzenie do nauki „oka umysłu” owocuje w psychologii szkołami introspekcyjnymi (psychoanaliza, gestalt, psychologia humanistyczna i egzystencjalna), a w filozofii - fenomenologią, hermeneutyką, egzystencjalizmem, teorią krytyczną. Wilber czyni kolejny krok i wprowadza „oko kontemplacji”, które odsłania rzeczywistość ducha za pomocą powtarzalnej i weryfikowalnej metodologii, a nie metafizycznej spekulacji.

\section{Integralny Pluralizm Metodologiczny}

Integralna filozofia Kena Wilbera, oparta na ewolucji świadomości, proponuje strukturę heurystyczną, która objęłaby wszystkie składowe meta-modelu AQAL, badane przez uznanych naukowców reprezentujących podejście nieredukcjonistyczne. Taki zbiór praktyk metodologicznych i dyrektyw odpowiadających metateorii AQAL, Wilber przedstawił w 2006 r. jako Integralny Pluralizm Metodologiczny (Integral Methodological Pluralism - IMP) ${ }^{14}$. Można powiedzieć, że IMP jest bardziej złożoną wersją ćwiartek.

Fundament IMP stanowi podejście post-metafizyczne do ontologii i epistemologii, zgodnie z którym Wilber przyjmuje, że rzeczywistość nie opiera się na wiecznych, ahistorycznych, podanych z góry strukturach ontologicznych, istniejących niezależnie od świadomości poznającego. Owe struktury postrzega on metaforycznie jako nawyki Kosmosu lub rodzaj Kosmicznych wspomnień, które wyłaniają się i utrwalają w drodze ewolucji, po części współtworzone (w czterech ćwiartkach - tetra-tworzone) przez ewoluującą świadomość poznającego podmiotu $^{15}$. Badacz pisze:

Świat nie jest dany z góry, istniejąc niezależnie i poza wszelkimi spostrzeżeniami. Ani wszystkie rzeczy nie są po prostu percepcjami. Raczej istnieje całkowita suma wzajemnie odsłaniających się rzeczy i zdarzeń [...]. W rzeczywistości znaczy to, że każda rzecz jest perspektywą, zanim będzie czymkolwiek innym. A to znaczy, że w świecie przejawionym nie ma percepcji, tylko perspektywy. [...] O ile wiemy lub możemy wiedzieć, świat przedstawiony składa się z czujących

${ }^{14}$ Por. K. Wilber, Integral spirituality..., s. 33-49; S. Esbjörn-Hargens, K. Wilber, Toward a comprehensive integration..., s. 529-536; S. Esbjörn-Hargens, An overview of integral theory..., s. 33-61; K. Koller, Architecture of integral science, „AQAL: Journal of Integral Theory and Practice" 2006, t. 1, No 2, s. 250-275; tenże, The data and methodologies of integral science, „AQAL: Journal of Integral Theory and Practice” 2006, t. 1, No 3, s. 158-183.

${ }^{15}$ Jednocześnie, podkreśla Wilber, te struktury rzeczywistości nie mają charakteru jedynie subiektywnego. Ewoluujące poziomy są trans-indywidualne, istnieją niezależnie od poszczególnego podmiotu, stanowiąc fakt, z którym każde ludzkie istnienie musi się zmierzyć, np. urzeczywistniając w procesie swego rozwoju daną strukturę-poziom. Te kolektywne Kosmiczne wspomnienia napierają na psychikę jednostki i kierują jej rozwojem. Por. K. Wilber, Integral spirituality ..., s. 239-248, 271-272. 
istnień z ich perspektywami, nie z rzeczy z ich własnościami, ani z podmiotów z ich percepcjami, ani z potencjałów próżni, ani z dharmy, ani ze strun, ani z hologramów, ani z biopól etc. ${ }^{16}$

Zgodnie z podejściem post-metafizycznym, w miejscu postrzegania Wilber umieszcza perspektywy. Cały Kosmos - w znaczeniu obejmującym wszystkie wymiary uniwersum: wewnętrzne i zewnętrzne - zbudowany jest ze wzajemnie odsłaniających się i oddziałujących na siebie perspektyw czujących istnień. Stanowisko post-metafizyczne zakłada, że przedmioty istnieją w przestrzeniach ustanowionych częściowo przez poznający podmiot. Zarówno poznający podmiot, jak i poznawany przedmiot są tu definiowane przez rozwojową wysokość (altitude), tj. ewolucyjny poziom rozwoju świadomości, oraz poprzez perspekty$\mathbf{w y}$, a nie przez niezmienne, na zawsze ustalone poziomy ontologiczne, które - zawieszone w ahistorycznym świecie - oczekują, by je ujrzeć. Tym samym, twierdzi Wilber, nie istnieje jeden świat dany z góry, a po prostu kontinuum światów, które wyłaniają się wraz z różnymi porządkami świadomości i są przez te porządki po części tworzone ${ }^{17}$.

Integralny Pluralizm Metodologiczny jest kierowany przekonaniem, że „Każdy ma częściową słuszność”. Wilber zakłada bowiem, że każda uzasadniona lub przekonująca perspektywa - każdej ćwiartki i każdego poziomu rozwoju - niesie pewną prawdę. Ta cząstkowa prawda dotyczy nie tylko danego poziomu rozwoju, lecz jest ważną i konieczną częścią wyższych poziomów. Niektóre z tych uzasadnionych perspektyw są pojemniejsze niż inne i włączają więcej pewników bądź prawdy bardziej adekwatne.

Każda z praktyk metodologicznych odsłania inny fragment lub aspekt rzeczywistości, przedstawiając prawdziwe, ale częściowe rozstrzygnięcia. Teoria integralna splata te cząstkowe prawdy ze sobą przy użyciu trzech heurystycznych reguł jednoczących: niewykluczania, odsłaniania i wprowadzania w życie.

1. Zasada niewykluczania (nonexclusion) oznacza uznanie wszystkich prawdziwych twierdzeń. Zgodnie z tą regułą, możemy uznać te twierdzenia, które zdały testy zasadności dla swych własnych paradygmatów we własnych dziedzinach (np. w naukach ścisłych, hermeneutyce, duchowości). Twierdzenia te mogą

\footnotetext{
${ }^{16}$ Tamże, s. 255.

${ }^{17}$ Przekonanie, że prawdziwa jest rzeczywistość taka, jaka jawi się w umyśle osoby, dana jako obiektywnie istniejąca i statyczna, Wilber nazywa mitem danego (myth of the given), monologicznym empiryzmem lub filozofią podmiotu. Oprócz wymienionego powyżej przekonania, mit danego zawiera: 1) wiarę, że świadomość jednostki dostarczy prawdę (świadomość introspekcyjna nie wystarcza, by ukazać np. prawdę intersubiektywną); 2) niezrozumienie, że prawda, którą jednostka głosi, jest do pewnego stopnia wytworzona i uformowana przez ponadosobiste powiązania i konteksty kulturowe; 3) przekonanie, że zwierciadło natury (monologiczny empiryzm) stanowi odpowiednią metodologię, zdolną odkryć inne dziedziny: transpersonalną, domenę ducha, świadomość planetarną, złożoność myślenia etc. Por. tamże, s. 175-176. Dogłębne omówienie tego tematu - tamże, s. 175-178, 231-284.
} 
orzekać o istnieniu własnych ujawnionych zjawisk, natomiast nie mogą rozstrzygać o istnieniu zjawisk ustanowionych $\mathrm{w}$ obrębie innych paradygmatów.

2. Zasada odsłaniania (unfoldment): pewne praktyki badawcze są pełniejsze, bardziej wszechstronne i odsłaniają więcej prawd niż inne. Jeśli przyjrzymy się np. liniom rozwoju (przykładowo moralnego czy poznawczego), to w obrębie dowolnej z nich pewne twierdzenia zawierają więcej głębi niż inne, włączają więcej prawdy.

3. Zasada wprowadzania w życie (enactment) - różne metody badań będą ujawniać różne zjawiska, w zależności od perspektywy badacza, którą tworzą ${ }^{18}$ : a) sposób, w jaki zyskuje on wiedzę (dyscyplina, którą reprezentuje, narzędzia, jakimi się posługuje); b) poziom rozwoju świadomości; c) poziom rozwoju w poszczególnych liniach (np. poznawczej, moralnej, interpersonalnej, duchowej); d) szczególny stan świadomości w danym czasie; e) osobisty styl lub typ (styl kulturowy, gender etc.).

Powyższe trzy reguły, zabezpieczające pozycję wszystkich perspektyw w rzeczywistości, odnoszą się do każdej wartościowej wiedzy i służą ochronie różnych form prawdy odkrywanych przez poszczególne metodologie.

Mając oparcie w trzech zasadach (braku wykluczania, ujawniania i wprowadzania w życie), Wilber przyjął, że rzeczywistość każdej z czterech ćwiartek badają dwa typy metodologii: podejścia, które analizują wnętrze ćwiartki oraz podejścia, które analizują daną ćwiartkę od zewnątrz. Idąc tym tropem, filozof uznał, że każdej osobie należy przypisać osiem podstawowych perspektyw - wewnętrzne i zewnętrzne spojrzenie danej osoby na zjawiska w każdym z czterech wymiarów doświadczenia (por. ryc. 3). Na przykład w wymiarze intencjonalnym (Górna Lewa ćwiartka) będą to dwie fundamentalne perspektywy:

- wewnętrzny (fenomenologiczny) widok własnego subiektywnego doświadczenia jednostki, np. poczucia pełni istnienia: mam, w tym momencie, wewnętrzne poczucie pełni istnienia.

- zewnętrzny (strukturalny) widok subiektywnego poczucia pełni istnienia, kiedy to poczucie staje się, przynajmniej w części, przedmiotem obserwującej świadomości osoby: przyglądam się mojemu poczuciu pełni istnienia jak ktoś z zewnątrz (tj. obiektywny lub „naukowy” obserwator). Należy zaznaczyć, że ten zewnętrzny (strukturalny) widok pojawia się częściej w wyniku obserwacji przez drugą osobę, np. psychologa, który dzięki rozmowie ma dostęp do subiektywnego świata jednostki.

Sumę tych ośmiu zasadniczych perspektyw Wilber nazywa integralnym perspektywizmem (Integral Perspectivism) ${ }^{19}$.

\footnotetext{
${ }^{18}$ M. D. Forman, A guide to integral psychotherapy: Complexity, integration, and spirituality in practice, New York 2010, s. 11.

${ }^{19}$ Aby przedstawić związki, w jakie wchodzą ze sobą te perspektywy, Wilber rozwinął nowy typ notacji matematycznej - Integralną Matematykę Perspektyw, zwaną też Integralnym Rachunkiem
} 


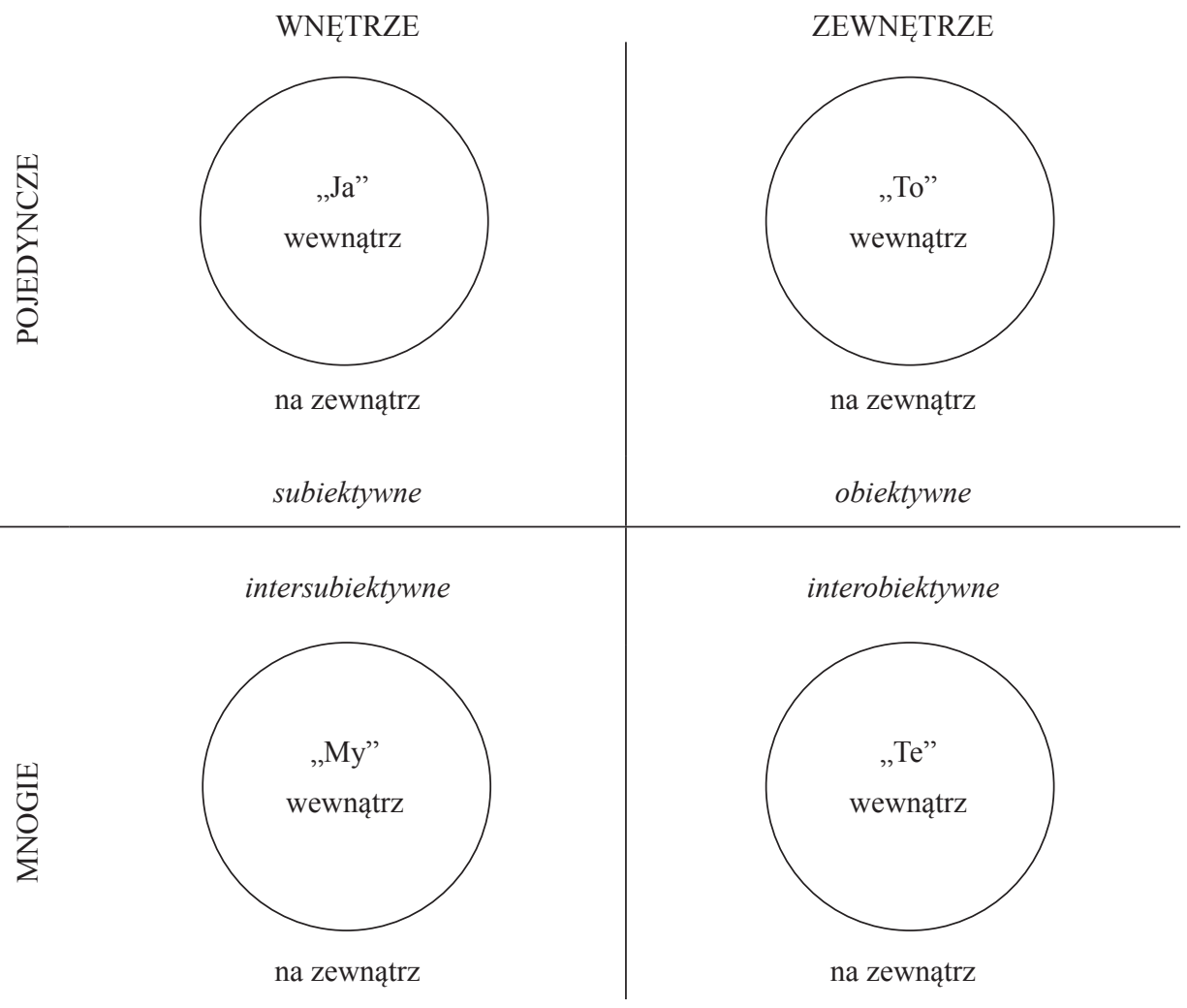

Ryc. 3. Osiem zasadniczych perspektyw

Źródło: K. Wilber, Integral spirituality. A startling new role for religion in the modern and postmodern word, Boston-London 2007, s. 36

(Integral Calculus) - gdzie miejsce tradycyjnych zmiennych zajęły perspektywy. Wilber używa m. in. następujących oznaczeń zmiennych: pierwsza osoba (1p) - dla określenia wnętrza w ogólności lub trzecia osoba (3p) - dla określenia zewnętrza w ogólności. Następnie łączy to z perspektywą wewnętrzną (1-p) albo perspektywą zewnętrzną (3-p) w liczbie pojedynczej, jak również z perspektywą wewnętrzną (1-p*pl) albo perspektywą zewnętrzną (3-p*pl) w liczbie mnogiej. Na przykład perspektywa psychologicznej introspekcji jest tu przedstawiana następująco: doświadczam w 1 osobie mojej 1-osobowej świadomości (albo inaczej: patrzę na mój umysł), co możemy zapisać jako 1-p x 1p. Możemy też spojrzeć na siebie z perspektywy 3 osoby, tj. obiektywnie. Będzie to spojrzenie 3 osoby na moją własną introspekcję, co obrazuje zapis: 3-p x 1-p x 1p. Inny przykład dotyczy medytacji, która jest tu widziana następująco: patrzę w 1 osobie (1-p) na moją 1-osobową świadomość (1-p) mnie (1p), co zapisujemy jako 1-p x 1-p x 1p. Wilber zaznacza, że wnętrze i zewnętrze jednostki i zbiorowości nie są tożsame z podejściem 1, 2 i 3 osoby. Po prostu ćwiartki (wnętrze/zewnętrze x pojedyncze/ /mnogie) są o wiele bardziej fundamentalne i generują podejście 1, 2 i 3 osoby. Por. K. Wilber, Integral Spirituality..., s. 40-42. Dokładne rozwinięcie tego tematu - zob. C. Fuhs, An integral map of perspective taking, [w:] Integral theory in action. Applied..., s. 281-301. 
Każdą z ośmiu podstawowych perspektyw - wewnętrzny i zewnętrzny obraz zjawisk w każdej z czterech ćwiartek - możemy odkryć za pomocą określonej metody badań lub określonej rodziny metodologicznej. Każda z metod badań odsłania inny aspekt rzeczywistości, niedostępny dla pozostałych metod. W pełni integralne podejście do badanego zjawiska zakłada, że nie zostanie pominięta żadna z ośmiu perspektyw i metod badawczych.

Stosownie do ośmiu podstawowych perspektyw, przyjąwszy jako kryterium podziału przedmiot badań, Wilber wyróżnia osiem rodzin metodologicznych ${ }^{20}$.

\section{Osiem rodzin metodologicznych (por. ryc. 4)}

Górna Lewa ćwiartka:

1) fenomenologia, która bada bezpośrednie doświadczenie - wnętrza wnętrz jednostki (the insides of individual interiors), (1-p x 1-p x 1p);

2) strukturalizm, który odsłania powtarzające się wzory doświadczeń - zewnętrzne strony wnętrz jednostki (the outsides of individual interiors), (1-p x 3-p x 1p);

Dolna Lewa ćwiartka:

3) hermeneutyka, która odkrywa ponadosobiste rozumienie - wnętrza zbiorowych wnętrz (the insides of collective interiors), (1-p x 1-p x 1p*pl);

4) etnometodologia, która odsłania powtarzające się wzory intersubiektywnego rozumienia - zewnętrzne strony zbiorowych wnętrz (the outsides of collective interiors), (1-p x 3-p x 1p*pl);

Górna Prawa ćwiartka:

5) teoria autopoiesis ${ }^{21}$, tj. samowytwarzania (self-creation), która przybliża samoregulujące się zachowanie - wnętrza powierzchni jednostki (the insides of individual exteriors), (3-p x 1-p x 3p), np. bada rodzaj struktury wewnętrznej, wyjaśniającej obserwowane zachowanie;

${ }^{20}$ Por. K. Wilber, Integral spirituality..., s. 35-37; S. Esbjörn-Hargens, Integral research: A multi-method approach to investigating phenomena, „Constructivism and the Human Sciences” 2006, t. 11 , No 1, s. 87-88.

${ }^{21}$ Powszechnie uważani za pionierów teorii autopoiesis, biolog Humberto Maturana i kognitywista Francisco Varela, odnoszą autopoiesis do samowytwarzania lub samoorganizowania się danego systemu. Chodzi tu o mechanizm, dzięki któremu ewoluujące systemy utrzymują swoją organizację i przekraczają entropię. Teoria integralna wywodzi autopoiesis z obserwacji biologicznej fenomenologii organizmu. Jak podaje Fuhs, kilka dekad przed publikacją Maturany i Vareli, koncepcję samoorganizacji przedstawili cybernetycy, Warren McCulloch i Walter Pitts, którzy na początku lat 40. XX w. opisali logikę systemów nerwowych jako samo-organizujących się. Dwie dekady później, von Foerster, zajmujący się złożonością matematyczną, zaproponował jakościowy model samoorganizacji. - Por. K. Wilber, Integral spirituality..., s. 169-172; M. Rentschler, AQAL glossary..., s. 3; C. Fuhs, Perspectival semiosis: Tentative proof that perspective are primordial, referat na The $2^{\text {nd }}$ Biennial Integral Theory Conference, John F. Kennedy University, Pleasant Hill, Kalifornia 29.07 - 1.08.2010. Na: www.integraltheoryconference.org/sites/default/files/itc-2010-papers/Fuhs_ITC\%202010.pdf (12.10.2010). 
6) empiryzm, który bada dające się obserwować zachowanie - zewnętrzne strony powierzchni jednostki (the outsides of individual exteriors), (3-p x 3-p x 3p);

Dolna Prawa ćwiartka:

7) teoria społecznej autopoiesis, która ukazuje samoregulującą się dynamikę zachowań w systemach - wnętrza zbiorowych powierzchni (the insides of collective exteriors), (3-p x 1-p x 3p*pl), np. to, jak grupy tworzą siebie, utrzymując wewnętrzną spójność i granice. Podejście to bada m. in. interakcje i artefakty, które są przedmiotem wymiany w systemach i grupach.

8) teoria systemów, która bada dopasowanie funkcjonalne poszczególnych części w dającej się zaobserwować całości - zewnętrzne strony zbiorowych powierzchni (the outsides of collective exteriors), (3-p x 3-p x 3p*pl).

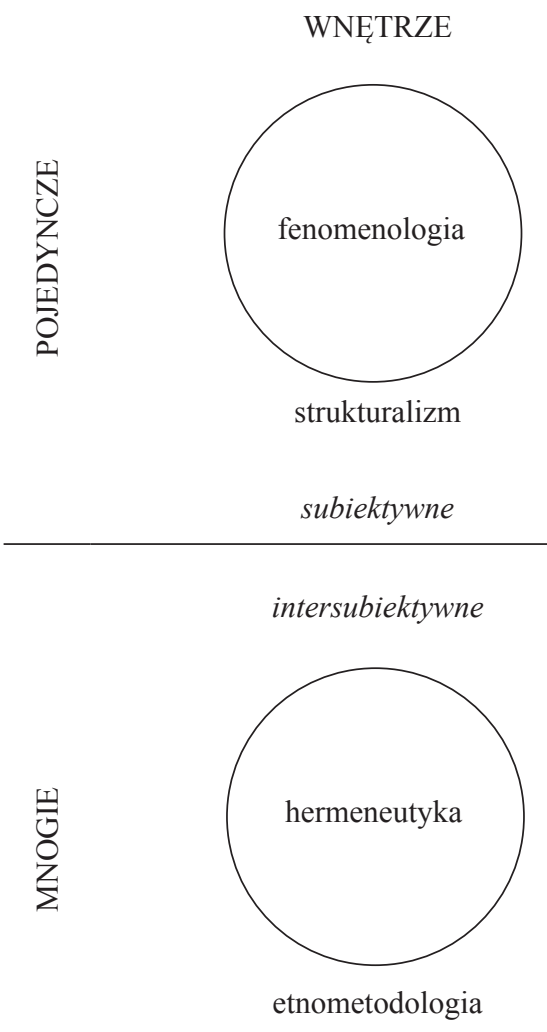

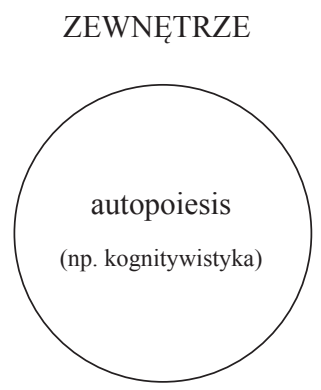

empiryzm (np. neurofizjologia)

obiektywne

interobiektywne

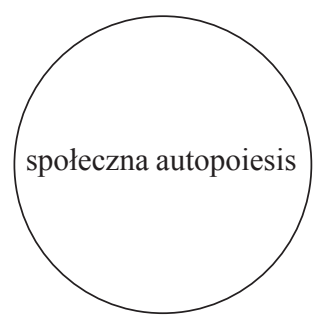

etnometodologia

Ryc. 4. Osiem głównych metodologii

Źródło: K. Wilber, Integral spirituality. A startling new role for religion in the modern and postmodern word, Boston-London 2007, s. 37 
Każda z tych rodzin metodologicznych jest swego rodzaju budowlą mogącą pomieścić wiele różnych metod badań, praktyk badawczych i zaleceń2 ${ }^{22}$. Na przykład rodzina fenomenologii obejmuje $\mathrm{m}$. in. introspekcję, badanie fenomenologiczne, medytację, kontemplację. Wymienione metody odkrywają wewnętrzny obraz wnętrza jednostki w wymiarze subiektywnym (Górna Lewa ćwiartka). Rodzina strukturalizmu włącza $\mathrm{m}$. in.: testy rozwojowe (np.: psychometryczne), testy na typ osobowości, wywiady z przyjaciółmi, rodziną i kolegami z pracy na temat samego siebie, metody analizy strukturalnej, prowadzenie dziennika, analizę informacji zwrotnych. Za pomocą tych metod można poznać zewnętrzny obraz wnętrza jednostki w wymiarze subiektywnym. Z kolei rodzina hermeneutyki mieści w sobie m. in.: analizę interpretacyjną, analizę tekstową, zbiorową refleksję, zbiorową introspekcję, wywiady. Metody te badają wewnętrzny obraz wnętrza zbiorowości w wymiarze intersubiektywnym. Rodzina etnometodologii obejmuje formy analizy kulturowej, badania naturalistyczne, analizę dialogową i in. Rodzina empiryzmu zawiera ankiety, obserwację, eksperyment, opisy konkretnych przypadków, analizę luk, badanie diagnostyczne, analizę statystyczną itd. Rodzina teorii systemów to z kolei m. in. ${ }^{23}$ : monitorowanie, dynamiczna symulacja systemów (badanie wyłaniających się interaktywnych zmiennych na różnych poziomach systemu i ewolucja systemu w czasie), modelowanie komputerowe, dynamiczna analiza sieci (łączy techniki analizy sieci społecznej z wieloczynnikowymi symulacjami).

Integralny Pluralizm Metodologiczny pozwala badaczowi całkowicie wykorzystać i skoordynować wiele podejść badawczych, a tym samym wszechstronnie zbadać, połączyć wnioski i w pełni zrozumieć badane zjawisko. Wilber podkreśla:

Fundamentalnym twierdzeniem Teorii Integralnej AQAL jest to, że każde podejście, które pomija którykolwiek z tych 8 paradygmatów jest mniej-niż-wystarczającym podejściem według dostępnej i pewnej wiedzy ludzkiej w obecnym czasie ${ }^{24}$.

\section{Trudności w stosowaniu Integralnego Pluralizmu Metodologicznego}

$\mathrm{Na}$ trudności w praktycznym stosowaniu Integralnego Pluralizmu Metodologicznego wskazuje Tom Murray ${ }^{25}$. Badacz ten utrzymuje, że w chwili, gdy otwieramy się na nowe perspektywy pojawia się problem nieokreśloności

${ }^{22}$ Interesujące rozwinięcie tego tematu - zob. K. Heikkinen, Integral mind, brain, and education, [w:] Integral education. New directions for higher learning, eds S. Esbjörn-Hargens, J. Reams, O. Gunnlaugson, New York 2010, s. 271-288.

${ }^{23}$ W. Küpers, J. Weibler, Inter-leadership: Why and how should we think of leadership and followership integrally?, „Leadership” 2008, No 4, s. 453-454.

${ }^{24} \mathrm{~K}$. Wilber, Integral spirituality..., s. 33.

${ }^{25}$ T. Murray, Exploring epistemic wisdom. Ethical and practical implications of integral studies and methodological pluralism for collaboration and knowledge-building, [w:] Integral theory in action. Applied, theoretical, and constructive perspectives on the AQAL model, red. S. Esbjörn-Hargens, New York 2010, s. 345-367. 
epistemologicznej (epistemic indeterminacy), związany z trudnościami w sferze emocjonalnej (uczucie niepewności, dwuznaczności, zamętu), w sferze poznawczej (paradoks oraz nieprzewidywalność komunikacji, koncepcji i modeli), a także z naszą elastycznością bądź jej brakiem w odniesieniu do tych treści ${ }^{26}$.

Powyższym trudnościom może zaradzić rozwój bardziej złożonych, postformalnych zdolności poznawczych. Zestaw takich zdolności Murray określa mianem mądrości epistemologicznej (epistemic wisdom) i wyróżnia w nim następujące postawy, współzależne umiejętności i meta-umiejętności ${ }^{27}$ : meta-kognicja (myślenie o myśleniu, tj. refleksja nad własnymi milczącymi przekonaniami, modelami mentalnymi, procesem rozwiązywania problemów, pewnością odnośnie do własnych wniosków), myślenie dialektyczne (zdolność rozpatrywania wielu perspektyw, elastyczne radzenie sobie z niepewnością, dwuznacznością, zmianą, niezgodnością oraz paradoksami konceptów, języka i wiedzy), empatia poznawcza (umiejętność postawienia się w czyjejś sytuacji), myślenie systemowe (szerokie widzenie sytuacji i jej wewnętrznych powiązań, branie pod uwagę wyższego poziomu potrzeb i kontekstów, skupienie na potrzebach grupy jako całości, rozważanie perspektywy wszystkich grup; widzenie dynamiki, hierarchii, dialektyki systemów oraz przeszłych, teraźniejszych i przyszłych możliwości wewnątrz nich), umiejętność epistemologiczna (rozumienie niuansów i różnic w sposobach operowania przez ludzi faktami, prawdą, przekonaniami, znaczeniem itd. i rozumienie różnych sposobów uzasadniania wiedzy), inteligencja społeczna i emocjonalna (refleksja nad swoimi uchybieniami, milczącymi intencjami, nieświadomymi motywacjami, treściami wypieranymi ze świadomości, stanami emocjonalnymi).

Mądrość epistemologiczna jest zatem zestawem zdolności, które pomagają obchodzić się z nieokreślonością epistemologiczną, to znaczy z niepewnością,

${ }^{26}$ Wymienione trudności Murray wiąże zarówno z ładunkiem poznawczym, jak i emocjonalnym. 1. Trudności związane $\mathrm{z}$ ładunkiem poznawczym to: a) szeroka złożoność, która łączy się ze zwiększeniem złożoności informacji, do czego dochodzi wskutek otwierania wielu perspektyw; b) złożoność hierarchiczna - człowiek stopniowo tworzy konstrukcje myślowe na coraz wyższym poziomie złożoności, rozwijając myślenie abstrakcyjne i zdolność generalizowania (zgodnie z podstawową zasadą, że poziom niższy integruje się do postaci pojedynczej idei na wyższym poziomie złożoności i abstrakcji); aby uznać nową perspektywę, jednostka musi osiągnąć określony poziom abstrakcji i generalizacji, co nie zawsze się udaje. 2. Trudności związane z ładunkiem emocjonalnym to: a) dysonans poznawczy - starając się pogodzić sprzeczne idee, ludzie często odczuwają dyskomfort; niepewność i dwuznaczność są bolesne dla umysłu; b) przywiązanie ego - ludzie odrzucają wielość perspektyw i idei, ponieważ są one niezgodne z ich przekonaniami czy poczuciem ,ja”. Dokładne omówienie problemu nieokreśloności epistemologicznej (w tym jej źródeł poznawczych, psychologicznych, społecznych i filozoficznych), jego konsekwencji, które - ignorowane - mogą prowadzić do nieważnej, ograniczonej i bezużytecznej wiedzy, a także sposobów radzenia sobie z tym dylematem - zob. T. Murray, Collaborative knowledge building and integral theory: On perspectives, uncertainty, and mutual regard, „Integral Review: A Transdisciplinary and Transcultural Journal for New Thought, Research, and Praxis" 2006, No 2, s. 210-268.

${ }^{27}$ Por. T. Murray, Exploring epistemic wisdom..., s. 345-367. 
dwuznacznością, zamętem, paradoksem oraz z nieprzewidywalnością komunikacji, koncepcji i modeli. To rodzaj epistemologicznej elastyczności, biegłości, płynności oraz świadomości. Mądrość epistemologiczna uświadamia nam znaczenie otwierania się na wiele perspektyw oraz wyposaża w umiejętności potrzebne do przyswojenia nowych, bardziej złożonych koncepcji. Wskazuje ona zarazem na taki etap rozwoju poznawczego, na którym osiągamy meta-poziom rozumienia procesów umysłowych i komunikacyjnych.

Wymienione powyżej składowe mądrości epistemologicznej są skutecznym narzędziem przezwyciężania trudności, które wyłaniają się np. przy praktycznym stosowaniu Integralnego Pluralizmu Metodologicznego.

\section{Przyklad: Badanie integralne na John F. Kennedy University}

Teoria integralna wspiera i kształtuje badania naukowe opierające się na Integralnym Pluralizmie Metodologicznym. IMP to obecnie najbardziej wszechstronny model obejmujący badania z perspektywy pierwszej, drugiej i trzeciej osoby. Struktura IMP służy do przygotowania i przeprowadzenia badań integralnych na John F. Kennedy University (JFKU), a zarazem rozwija te badania.

Kurs Badania Integralne jest obowiązkowy dla studentów II roku psychologii na tej uczelni ${ }^{28}$. Składa się on z dwóch części - A oraz B i ma za zadanie przybliżyć studentom podstawy badania integralnego, a także przeobrazić ich poprzez odkrywanie złożonych relacji między epistemologią, ontologią i metodologią $\mathrm{w}$ procesie dochodzenia do prawdy o badanym zjawisku. Studenci w trakcie kursu prowadzą własne projekty badawcze.

Początek kursu to poznawanie historii i koncepcji projektu badawczego oraz wybór tematu badań ${ }^{29}$. Wybrany przez studenta temat będzie następnie eksplorowany za pomocą sześciu różnych metod, reprezentujących perspektywę pierwszej, drugiej i trzeciej osoby (Ja, To, My). Studenci systematycznie pracują nad tematami swoich badań, rozwijają je i przygotowują strategię badawczą. W dalszej kolejności uczą się historii i założeń badania integralnego oraz przedstawiają tematy własnych projektów badawczych.

Studenci rozpoczynają swoje badania, przyjmując perspektywę pierwszej osoby: piszą autobiografię i krytycznie oceniają swoje mocne i słabe strony. Uwzględniają przy tym swój obecny poziom rozwoju w poszczególnych liniach (np. poznawczej, moralnej, kinestetycznej), różne stany świadomości, których doświadczają, a także określają swój typ osobowości. Powyższe metody - autobiografia i krytyczna samoocena - pozwalają studentom ujrzeć, w jaki sposób ich własna świadomość i doświadczenia życiowe wpływają na badania.

\footnotetext{
${ }^{28}$ Por. S. Esbjörn-Hargens, Integral research: A multi-method..., s. 79-107.

${ }^{29}$ Tamże, s. 90-92.
} 
Następnie studenci obierają perspektywę drugiej osoby, badając proces przeprowadzania wywiadu oraz kodowania informacji. W tym celu każdy z nich przeprowadza około godzinny wywiad z jedną wybraną osobą, zapisując go przy użyciu dowolnej techniki oraz kodując uzyskany materiał pod kątem własnych badań. Potem wykorzystują etnometodologię, aby aktywnie „uczestniczyć” w temacie badawczym.

Badanie z wykorzystaniem perspektywy trzeciej osoby student rozpoczyna od tworzenia ankiety związanej z tematem badań. Ankietę zawierającą 10-20 pytań przeprowadza następnie w grupie liczącej około 20 osób, a uzyskane dane poddaje analizie ilościowej. Wyniki przedstawia w postaci prostych wykresów, które obrazują liczbę wszystkich możliwych odpowiedzi na poszczególne pytania. Dopełnieniem ankiety może być protokół, w którym studenci zapisują swoje szczególne obserwacje dotyczące badania (np. mogą umieścić w nim informacje na temat ciśnienia krwi, mierzonego o różnych porach w ciągu dnia ich pracy badawczej, w celu określenia czynników stresu i miejsca pracy). Ostatnią metodą w projekcie badawczym jest analiza systemów. Przeprowadzenie tej części badania wymaga od studentów przestudiowania literatury i wyboru tekstów źródłowych do własnej analizy systemów. Wybrane źródła pomogą odnieść temat danego badania do konkretnego systemu (np. ekonomii, dynamiki politycznej, wymiarów prawa, informacji ekologicznej).

W zarysowanym powyżej projekcie badawczym studenci odwołują się do sześciu (z ośmiu) obszarów badań. Sean Esbjörn-Hargens podaje, że wyłączenie z projektu badań dwóch pozostałych obszarów - teorii autopoiesis i teorii społecznej autopoiesis - jest spowodowane dwiema trudnościami. Pierwsza niedogodność płynie z tego, że obie te rodziny metodologiczne operują spojrzeniem od wewnątrz na rzeczywistość zewnętrzną (the inside view of exterior realities), a to sprawia, że trudno je zrozumieć i posłużyć się nimi bez dodatkowego treningu, którego nie przewidziano w programie studiów. Drugą niedogodność powoduje brak czasu jest go za mało, aby zająć się w praktyce ośmioma rodzinami metodologicznymi - ledwie starcza go na omówienie sześciu i umożliwienie studentom ich praktycznego zastosowania. Metody wybrane do projektu badawczego nie wymagają od studentów rozległego i intensywnego ćwiczenia metodologii związanych z każdym z ośmiu obszarów, a pozwalają im przeprowadzić ich obecne badania.

Naukowe cele kursu Badanie Integralne zakładają m. in., że studenci ${ }^{30}: 1$ ) odkryją i wyjaśnią w formie pisemnej związki między epistemologią, ontologią i metodologią; 2) wskażą i opiszą główne elementy metod wchodzących w skład Badania Integralnego; 3) wyjaśnią perspektywę pierwszej, drugiej i trzeciej osoby, a także podadzą przykłady metod badań związanych z każdą z tych perspektyw; 4) przygotują i przeprowadzą własny projekt badawczy, obierając perspektywy pierwszej, drugiej i trzeciej osoby (tj. subiektywną, intersubiektywną i obiektywną).

${ }^{30}$ Tamże, s. 92. 
Wszyscy studenci są zobowiązani dostarczać co tydzień część swojej pracy badawczej (około czterostronicowy opis jednej z sześciu metod, podzielony na pięć części: wprowadzenie, metoda, dane, kryteria zasadności i omówienie), co zmusza ich do systematycznej pracy nad projektem. Mają również obowiązek uczestniczyć w konsultacjach prowadzonych przez Centrum Wspierania Studentów na terenie JFKU, które pomagają im opisać i przedstawić końcowy projekt badań. Prowadząc własne projekty, młodzi ludzie mają duży wybór sposobów działania - dysponują różnorodnymi praktykami, które służą ich przedsięwzięciom badawczym. Esbjörn-Hargens przedstawia niektóre przykłady praktyk badawczych dla każdego z sześciu obszarów badań, a także kryteria ich zasadności ${ }^{31}$ :

\section{Techniki fenomenologiczne (1p x 1-p x 1p)}

Samobadanie, badanie fenomenologiczne, praktyki świadomości zmystowej i/lub somatycznej, wizualizacja, modlitwa, refleksja, introspekcja, prowadzenie dziennika, praca twórcza, poezja, ruch, pisanie autobiografii, Gendlin's focusing, obieranie różnych perspektyw, medytacja, joga, tai chi, vision-quests, zapisywanie snów, praktyki umystowe, ,praca z cieniem”.

Kryteria słuszności: szczerość, prawdziwa ekspresja, obszerne opisy, uczciwość, integralność, podatność, identyfikowanie zatożeń, transformacyjność, uznanie stronniczości (acknowledge bias).

\section{Techniki strukturalistyczne (1p x 3-p x 1-p)}

Różne rodzaje testów rozwojowych (np. psychometryczne) sprawiaja, że wyniki sa prawdziwe $w$ maksymalnym stopniu, testy na typ osobowości, wywiady z przyjaciótmi, rodzina i kolegami z pracy na temat samego siebie, prowadzenie dziennika i zauważanie wzorów, wywiady podmiot-przedmiot, testy kończenia zdań, oceny uzyskanie od mentorów i nauczycieli duchowych, analiza psychografu, oglądanie nagrań z samym soba, stuchanie nagrań z soba samym, zauważanie wzorów zachowań i mowy, informacje zwrotne.

Kryteria stuszności: opracowane testy psychologiczne, wykorzystanie opracowanych modeli rozwojowych, krytyczna subiektywność, badanie dhugoterminowe, obszerne opisy wraz z analiza, ,triangulation”, samoobserwacja, informacje zwrotne.

\section{Techniki hermeneutyczno-interpretacyjne (1p x 1-p x 1p*pl)}

Wywiady, odgrywanie ról, dialog i debata, praca w małych grupach ( $w$ dwójkach lub trójkach), obrzędy i zajęcia grupowe, grupy dyskusyjne, opowiadanie historii, branie udzialu $w$ przedstawieniach, analiza interpretacyjna, analiza tekstowa, zbiorowa refleksja i ćwiczenia z wizualizacji, zbiorowa introspekcja, różne metodologie uczestniczace, grupy fokusowe, ćwiczenia budujące zaufanie,

\footnotetext{
${ }^{31}$ Tamże, s. 93-101.
} 
komunikacja bez przemocy, mediacja i rozwiazywanie konfliktów, improwizacja aktorska, taniec, jazz, sztuki walki, spotkania międzygatunkowe.

Kryteria stuszności: oddanie głosu innym, stużba społeczności, odwzajemnianie, honorowanie innych, zaufanie, czlonkostwo, wzajemne zrozumienie, emancypacja, rezonans, symbolizm i petnia znaczenia.

\section{Techniki etnometodologiczne (3p x 3-p x 1-p*pl)}

Techniki uczestnik-obserwator, ocena uczestnictwa, formy analizy kulturowej, ,wdzięczne” badanie (appreciative inquiry), techniki antropologii kultury, formy analizy strukturalnej, informacje zwrotne na temat czyjejśs roli w zespole, rodzinie lub terapii par, aktywno-obserwacyjne rodzicielstwo, głosowanie, coaching $i$ mentoring, inscenizacje.

Kryteria stuszności: cross-kulturowa, obserwacja dynamiki grup, spójność symboliczna, dobrze udokumentowane obserwacje, dtugoterminowe zaangażowanie, sprawdzanie czlonka grupy i akceptacja grupy.

\section{Techniki empiryczno-obserwacyjne (3p x 3-p x 3p)}

Ankiety, dokumentacja, egzaminy, badania terenowe, obserwacja, opis i raporty z perspektywy trzeciej osoby, wykorzystywanie tabel, wykresów i statystyk do przedstawiania informacji, ćwiczenia i dieta, wywiady otwarte, techniki obserwacji uczestniczacej $w$ różnych działaniach $i$ sesjach, przeglad dokumentacji, opisywanie i rozpowszechnianie konkretnych przypadków, analiza luk, badanie diagnostyczne, oceny, budowanie umiejętności, rozwój zdolności technicznych/ /społecznych, anonimowe recenzje i gtosowania.

Kryteria stuszności: powtarzalność, warunki kontrolowane, empiryczność, logika, mierzalność, ciagła obserwacja, postugiwanie się wieloma zmysłami, wysoki współczynnik informacji zwrotnych, jasna forma pytań, reprezentatywne próbki.

Techniki analizy systemów (3p x 3-p x 3-p* pl)

Analiza statystyczna, mapowanie (mapping), studia naukowe, studia nad literatura tematu, monitoring $i$ ocena.

Kryteria stuszności: dopasowanie funkcjonalne, powtarzalność, warunki kontrolowane, empiryczność, logika, cenione źródta, wiele źródet i bezpośrednie doświadczenie systemu.

Wymienione powyżej techniki badawcze studenci dowolnie łączą na wiele sposobów, tak aby je spożytkować we własnych badaniach. Spośród zagadnień, jakie studenci podejmowali $\mathrm{w}$ ramach badania integralnego Esbjörn-Hargens przywołuje $\mathrm{m}$. in. następujące ${ }^{32}$ : dobrowolne wyrzeczenie się, transformacyjna

${ }^{32}$ Por. tamże, s. 95. 
moc zabawy, inteligencja emocjonalna w miejscu pracy, bieganie jako praktyka duchowa, symbolika bieli i czerwieni w snach, tożsamość kobieca, pedagogika coachingu, zależność między jogą a strachem, związek pomiędzy świadomością a zmianą społeczną.

Zarysowana powyżej struktura oparta na Integralnym Pluralizmie Metodologicznym umożliwia studentom szerokie i elastyczne podejście do tematów własnych badań. Mogą oni stosować wiele różnych praktyk badawczych, z których każda niesie ważne, ale częściowe rozstrzygnięcia, i które - połączone w projekcie - tworzą bardziej wszechstronny obraz badanego zjawiska. Dla wielu studentów kurs Badanie Integralne jest pierwszą w życiu sposobnością samodzielnego odkrywania prawd naukowych, co jest ekscytującym wydarzeniem.

\section{Przykładowy projekt badania integralnego - struktura pracy końcowej studenta ${ }^{33}$}

Wprowadzenie (3-5 stron)

Przedstaw temat swojego badania.

Wyjaśnij, dlaczego go wybrateś.

Podaj kilka powodów, dla których temat jest ważny.

Wyjaśnij, dlaczego stosowanie mieszanych metod badań jest cenne.

Omów strukturę postugiwania się metodami związanymi z perspektywa pierwszej, drugiej i trzeciej osoby.

W jednym, jasnym zdaniu przedstaw twoje pytanie badawcze.

Podaj swoje mieszane metody.

Wyjaśnij kontekst projektu badawczego (dtugość badania, lokalizacja itd.).

Opisz w jednym lub dwóch akapitach swoje założenia dotyczace badania.

Przedstaw ,mapę” dalszych części projektu.

\section{Czesść dotyczaca perspektywy pierwszej osoby}

Wprowadzenie (1-2 strony)

Opisz krótko metody pierwszej osoby i przedstaw w kilku zdaniach te, które wybrałeś. Na przyktad: analiza fenomenologiczna (opis autobiograficzny) i analiza strukturalna (opis samooceniajacy). Zadaj ,mini” pytanie badawcze każdej $z$ metod (np.: przeformuluj podstawowe pytanie w forme specyficzna dla meto$d y)$.

${ }^{33}$ Tamże, s. 96-102. 
Pierwsza metoda

Metoda autobiograficzna i projekt badania (1-2 strony)

Przedstaw ogólna metodologię, która się postużteś.

Wyjaśnij, dlaczego ta metoda jest odpowiednia dla tematu twojego badania.

Wyjaśnij, co ta metoda może, a czego nie może zgłębić w twoim temacie.

Objaśnij szczegółowo projekt twojego badania, krok po kroku.

Dane badania autobiograficznego (2-3 strony)

Przedstaw ogólny zarys analizy danych: kategorie, motywy, wglady.

Przedstaw dostowne przykłady (np.: obszerne opisy).

Jeśli to stosowne, użyj tabel $i$ wykresów, prezentując dane.

Omów zagadnienia i kategorie zasadności.

Dyskusja (1-2 strony)

Omów kategorie, motywy i wglady w powiąaniu z tematem twojego badania.

Zbadaj, jak zmienito się twoje rozumienie tematu badania.

Opisz, co się potwierdziło, a co cię zaskoczyło.

Wyjaśnij, co innego zrobiłbyś następnym razem.

Druga metoda

Metoda strukturalna i projekt badania (1-2 strony)

Przedstaw ogólna metodologię, która się postużyłeś (np.: poziomy rozwoju, enneagram).

Wyjaśnij, dlaczego ta metoda jest ważna dla tematu twojego badania.

Wyjaśnij, co ta metoda może, a czego nie może zgłębić w twoim temacie.

Objaśnij szczegółowo projekt swojego badania, krok po kroku.

Dane badania strukturalnego (2-3 strony)

Przedstaw ogólna analizę danych: twoje poziomy, linie, stany i typy.

Przytocz przykłady ze swojego życia ilustrujace tę ocenę.

Jeśli to stosowne, postuż się wykresami i tabelami, przedstawiając dane.

Omów zagadnienia i kategorie stuszności.

Dyskusja (1-2 strony)

Połacz autoanalizę z tematem twojego badania, jakie sa główne motywy, wglady.

Zbadaj, jak zmieniło się w tym procesie twoje rozumienie tematu badania.

Opisz, co się potwierdzito, a co cię zaskoczyło.

Wyjaśnij, co innego zrobiłbyś następnym razem. 


\section{Część dotyczaca perspektywy drugiej osoby}

Wprowadzenie (1-2 strony)

Opisz krótko metody drugiej osoby i przedstaw w kilku zdaniach te, które wybrateś. Na przykład: analiza hermeneutyczna i analiza etnometodologiczna. Zadaj „,mini” pytanie badawcze kazdej z metod (np.: przeformuluj podstawowe pytanie $w$ formę specyficzna dla metody).

Pierwsza metoda

Metoda hermeneutyczna i projekt badania (1-2 strony)

Przedstaw ogólna metodologię, która się postużyteś.

Wyjaśnij, dlaczego ta metoda jest odpowiednia dla tematu twojego badania.

Wyjaśnij, co ta metoda może, a czego nie może zgłębić w twoim temacie.

Wyjaśnij, z kim przeprowadzałeś wywiad i dlaczego.

Objaśnij szczegółowo, krok po kroku, projekt swojego badania metoda wywiadu.

Omów szczegóty działań przed wywiadem i po jego przeprowadzeniu.

Wyjaśnij proces kodowania i zasady, którymi się postużyteś.

Dane badania hermeneutycznego (2-3 strony)

Przedstaw ogólna analize danych: kategorie, motywy $i$ wglady.

Przedstaw dostowne przykłady 2-3 zapisanych cytatów odnośnie do każdego motywu, kategorii itd.

Jeśli to stosowne, postuż się tabelami i wykresami, prezentując dane.

Omów zagadnienia i kategorie stuszności.

Dyskusja (1-2 strony)

Omów kategorie, motywy $i$ wglady w powiazaniu z tematem badania.

Zbadaj, jak zmieniło się twoje rozumienie tematu badania.

Opisz, co się potwierdzito, a co cię zaskoczyło.

Wyjaśnij, co innego zrobitbyś następnym razem.

Druga metoda

Metoda etnometodologiczna i projekt badania (1-2 strony)

Przedstaw ogólna metodologię, która się postużyteś.

Wyjaśnij, dlaczego ta metoda jest odpowiednia dla tematu twojego badania.

Wyjaśnij, co ta metoda może, a czego nie może zgłębić w twoim temacie.

Objaśnij szczegółowo, krok po kroku, projekt twojego badania uczestniczącego.

Wyjaśnij, w jaki sposób udokumentowateś swoje uczestnictwo (np.: czy spisateś wydarzenia później, czy robiteś notatki w trakcie, czy zanotowateś wglady i wspomnienia/sny z kolejnych dni). 


\section{Dane badania etnometodologicznego (2-3 strony)}

Przedstaw ogólna analize danych, $n p$. intersubiektywne wzory zaobserwowane w grupie.

Przedstaw szczególy dotyczace twojego uczestnictwa i opisz, co zauważyleś w odniesieniu do przestrzeni intersubiektywnej, jak dzielono wspólne znaczenie i pojawiat się rezonans, jaka dynamika kulturowa odegrała największa rolę, czy zdarzyły się nieporozumienia, czy byteś osoba dobrze poinformowana, czy outsiderem itd. Jeśli to stosowne postuż się tabelami i wykresami, prezentujac dane.

Omów zagadnienia i kategorie stuszności.

Dyskusja (1-2 strony)

Połacz twoje uczestnictwo z tematem badania, przedstaw, jakie sa najważniejsze motywy, wglady.

Zbadaj, jak zmienito się twoje rozumienie tematu badania w tym procesie.

Opisz, co się potwierdzito, a co cię zaskoczyło.

Wyjaśnij, co innego zrobitbyś następnym razem.

\section{Cześć dotyczaca trzeciej osoby}

Wprowadzenie (1-2 strony)

Opisz krótko metody trzeciej osoby i przedstaw w kilku zdaniach te, które wybrateś. Na przykład: analiza empiryczna (ankieta i obserwacja) $i$ analiza systemów. Zadaj ,mini” pytanie badawcze każdej z metod (np.: przeformuluj podstawowe pytanie w formę specyficzna dla metody).

Pierwsza metoda

\section{Metoda analizy empirycznej i projekt badania (1-2 strony)}

Przedstaw ogólna metodologię, której użyeś przy tworzeniu ankiety (i planowaniu obserwacji).

Wyjaśnij, dlaczego ta metoda pasuje do tematu badań.

Wyjaśnij, co ta metoda może, a czego nie może zgłębić w twoim temacie.

Wyjaśnij, do kogo skierowateś ankietę (co lub kogo obserwowateś) $i$ dlaczego.

Opisz, co pragnałeś osiagnać przeprowadzając ankietę, komu ją dateś i dlaczego, tatwo czy trudno byto otrzymać ja z powrotem.

\section{Dane analizy empirycznej (2-3 strony)}

Przedstaw ogólna analizę danych ilościowych (np. liczba odpowiedzi na jedno pytanie).

Przedstaw tabele, wykresy, statystyki etc. prezentujace danelliczbe odpowiedzi $i$ wskaż, ile odpowiedzi otrzymałeś na każde pytanie (oraz to, co zaobserwowateś). Omów zagadnienia i kategorie stuszności. 
Dyskusja (1-2 strony)

Omów motywy $i$ wglady w powiąaniu z tematem badań.

Zwróć uwage, jak zmienito się twoje rozumienie tematu.

Opisz, co się potwierdzito, a co cię zaskoczyło.

Wyjaśnij, co innego zrobiłbyś następnym razem.

Druga metoda

Metoda analizy systemów i projekt badania (1-2 strony)

Wyjaśnij, który system wybrateś i dlaczego.

Przedstaw ogólna metodologię, która się postugiwateś (np. badanie źródet, obserwacja).

Opisz, w jaki sposób udokumentowateś wyniki swoich badań.

Wyjaśnij, dlaczego wybrana metoda jest odpowiednia dla tematu twoich badań.

Wyjaśnij, co ta metoda może, a czego nie może zgłębić w twoim temacie.

Dane badania metoda analizy systemów (2-3 strony)

Przedstaw ogólny zarys wyników badania.

Przedstaw szczegółowe przyklady tego, w jaki sposób system odnosi się do tematu twoich badań.

Jeśli to stosowne, postuż się wykresami i tabelami, przedstawiając dane.

Omów zagadnienia i kategorie zasadności.

\section{Dyskusja (1-2 strony)}

Połacz twoje uczestnictwo z tematem badań, jakie sa najważniejsze motywy/wgla$d y$.

Zbadaj, jak twoje rozumienie tematu badań zmieniło się w tym procesie.

Opisz, co się potwierdzito, a co cię zaskoczyto.

Wyjaśnij, co innego zrobitbyś następnym razem.

Wnioski (3-5 stron)

Streszczenie ogólnego badania.

Omówienie implikacji wyników badań.

Refleksja nad twoja rola w ujawnianiu danych oraz własna transformacja.

Przedstawienie w ogólnym zarysie ograniczeń studium badawczego.

Rekomendacje dla przyszlych badań.

Odniesienie studium badawczego do wyników osobistych i zawodowych.

Spoleczne znaczenie studium badawczego.

Kreatywne zakończenie: „serce” $i$ inspiracja tego studium badawczego dla ciebie, badacza. 
Bibliografia (2-3 strony)

Przedstaw listę wszystkich źródet omawianych lub wykorzystanych w pracy.

Załączniki (różnej dlugości).

Stwórz oddzielny załącznik dla każdego z poniższych elementów:

Pytania użyte w wywiadzie, stworzone przed wywiadem.

Niepodpisana kopia pracy.

Listy, wykresy, tabele poziomów, kategorii, motywów etc.

Kopia twojej ankiety.

Opcjonalnie:

Notka autobiograficzna

Wpisy z dziennika (np. osobiste, zapisy snów)

Tabela dowolnego modelu rozwojowego, z opisem etapów

Wysłany list z podziękowaniem

Notatki z uczestnictwa

Raporty obserwacyjne

Inne pomocne i odpowiednie mteriały 